\title{
Review \\ Cell-Free DNA Methylation as Blood-Based Biomarkers for Pancreatic Adenocarcinoma-A Literature Update
}

\author{
Stine Dam Henriksen ${ }^{1,2, *(D)}$ and Ole Thorlacius-Ussing ${ }^{1,2}$ \\ 1 Department of Gastrointestinal Surgery, Aalborg University Hospital, 9000 Aalborg, Denmark; otu@rn.dk \\ 2 Clinical Cancer Research Center, Aalborg University Hospital, 9000 Aalborg, Denmark \\ * Correspondence: stdh@rn.dk
}

check for

updates

Citation: Henriksen, S.D.;

Thorlacius-Ussing, O. Cell-Free DNA

Methylation as Blood-Based

Biomarkers for Pancreatic

Adenocarcinoma-A Literature Update.

Epigenomes 2021, 5, 8. https://

doi.org/10.3390/epigenomes5020008

Academic Editors: Martin

E. Fernandez-Zapico and

Christopher Pin

Received: 15 March 2021

Accepted: 6 April 2021

Published: 9 April 2021

Publisher's Note: MDPI stays neutral with regard to jurisdictional claims in published maps and institutional affiliations.

Copyright: (c) 2021 by the authors. Licensee MDPI, Basel, Switzerland. This article is an open access article distributed under the terms and conditions of the Creative Commons Attribution (CC BY) license (https:// creativecommons.org/licenses/by/ $4.0 /)$.

\begin{abstract}
Pancreatic adenocarcinoma has a horrible prognosis, which is partly due to difficulties in diagnosing the disease in an early stage. Additional blood-born biomarkers for pancreatic adenocarcinoma are needed. Epigenetic modifications, as changes in DNA methylation, is a fundamental part of carcinogenesis. The aim of this paper is to do an update on cell-free DNA methylation as blood-based biomarkers for pancreatic adenocarcinoma. The current literature including our studies clearly indicates that cell-free DNA methylation has the potential as blood-based diagnostic and prognostic biomarkers for pancreatic adenocarcinoma. However, still no clinical applicable biomarker for pancreatic adenocarcinoma based on DNA methylation do exist. Further well-designed validation studies are needed.
\end{abstract}

Keywords: pancreatic cancer; pancreatic ductal adenocarcinoma; epigenetic; DNA methylation; diagnostic biomarker; prognostic biomarker; cell-free DNA

\section{Introduction}

Pancreatic adenocarcinoma (PDAC) is the fourth leading cause of cancer death with a five-year survival rate less than $10 \%$ [1]. A crucial reason for the poor prognosis is that many patients are diagnosed with late-stage disease, which unfortunately makes curative treatment impossible.

Actually, the only clinical available biomarker for PDAC is carbohydrate antigen-19-9 (CA-19-9). CA-19-9 has prognostic properties, as elevated levels are more common in advanced cancer stages. Further, preoperative increased level of CA-19-9 is associated with decreased survival and low resectability rate [2,3]. Unfortunately, CA-19-9 lacks sufficient sensitivity and specificity for use as a diagnostic marker [4,5]. In addition, $10 \%$ of the population lacks the ability to produce CA-19-9 due to Lea-b-blood group status [2,4,6].

It would be a major advance for patients if additional blood-borne biomarkers were available to facilitate the detection of PDAC at an early stage. A blood-based diagnostic marker for PDAC would be ideal for screening high-risk individuals or even in patients with an intermediate risk of developing PDAC, such as patients with chronic pancreatitis, late-onset diabetes and familiar disposition to PDAC [7]. Such biomarkers could serve as a supplement to existing clinical tools in the diagnostic work-up of patients suspected of PDAC. Furthermore, additional prognostic biomarkers would be highly beneficial by facilitating the initial identification of patients with more aggressive tumor biology, optimize therapeutic decision making and promote individualized therapy.

The objective of this present paper is to give an update on the current literature on cell-free DNA methylation as blood-based biomarkers for PDAC.

\section{The Importance of Blood-Based Biomarkers for PDAC}

Blood-based markers have several advantages over tissue-based markers. The current standard of care for diagnosing PDAC involves examination of tumor tissue either by fine needle aspiration cytology or histological examination of biopsies or surgical specimens [8], 
which all are invasive procedures entailing a risk of complications. Blood-based tests are minimally invasive, involving only limited discomfort, and have no major complications. They can easily be repeated to enable close monitoring of the disease to evaluate response to treatment or early detection of recurrence [9-11].

As pancreas, or at least part of it, is difficult to access for any kind of tissue sampling, it calls for much easier methods as liquid biopsies. In addition, the size of the tumor may limit the ability to sample tissue adequately, and tissue biopsies may not be an accurate representation of the tumor due to intra-tumor heterogeneity [11-13]. There can also be molecular differences between the primary tumor and metastatic lesions, and thus a tissue biopsy from the primary lesion most likely will not represent the metastatic lesions [12]. In cases where tumor tissue specimens are unavailable from either the primary tumor or the metastatic lesions, blood-based markers may represent an alternative or a supplement to existing tools used in the diagnostic work-up and treatment of PDAC [11-13].

\section{Cell-Free DNA}

The presence of cell-free DNA in peripheral blood has been known for decades [14]. Cell-free DNA in the serum of patients with cancer was first described in 1977, where it was shown that patients with cancer had a larger amount of cell-free DNA than healthy individuals [15]. In 1983, similar results were described for pancreatic disease: PDAC patients had significantly higher levels of cell-free DNA compared to patients with chronic or acute pancreatitis [16].

The biology of cell-free DNA remains to some extent unclear. However, the release of nucleic acids into the blood is thought to be related to the apoptosis and necrosis of cancer cells or secretion by cancer cells [17]. Furthermore, it has been suggested that a part of the cell-free DNA may act as micrometastases or originate from circulating tumor cells undergoing cell death [17].

Tumors are usually heterogenic, with a mixture of different cancer cell clones and normal cell types, resulting in the release of both tumor-derived and wild-type cell-free DNA into the blood during tumor progression $[14,17]$. It is still challenging to differentiate circulating tumor DNA from circulating non-tumor DNA. This challenge is enhanced by the fact that several benign conditions also are associated with an increased level of cell-free DNA due to the shedding of nucleic acids into the blood by apoptotic and necrotic cells $[18,19]$. In recent years, free circulating or cell-free DNA have become of major interest as tools for minimal invasive diagnostics, i.e., "liquid biopsy". It is an alternative approach to cancer tissue biopsy for analyzing genetic and epigenetic aberrations.

\section{DNA Methylation}

DNA methylation consists of the addition of a methyl $(\mathrm{CH} 3)$ residue to a cytosine preceding a guanosine, known as a $\mathrm{CpG}$ dinucleotide [20-22]. CpG dinucleotides are in $\mathrm{CpG}$-rich regions known as $\mathrm{CpG}$ islands, where the majority of methylated $\mathrm{CpG}$ dinucleotides are in repetitive intragenomic sequences. Furthermore, $60 \%$ of genes in the human genome contain one or more $\mathrm{CpG}$ islands in the promoter region. However, only $5 \%$ of these promoter sequences are methylated under normal conditions [20-22]. Methylated DNA results in a tightly packed chromatin structure, and unmethylated DNA is associated with lightly packed chromatin [20]. Aberrant DNA methylation (hypo- and hypermethylation) is a fundamental part of carcinogenesis. Global DNA hypomethylation of repetitive sequences is a part of early carcinogenesis and may lead to chromosomal instability. DNA hypermethylation often occurs in the $\mathrm{CpG}$ islands of the promoter sequences of genes. Hypermethylation in the promoter regions of tumor suppressor genes result in downregulation/silencing of tumor suppressor function, whereas hypomethylation in promoter regions of oncogenes may result in increased gene expression [20,21].

In PDAC aberrant methylation has been shown in precursor lesion of the pancreas $[23,24]$. A progressive increase in the prevalence of methylation has been demonstrated with 
increasing dysplasia and it has been suggested that specific genes can be target for aberrant methylation at different stages of pancreatic neoplastic progression [23-25].

\section{Cell-Free DNA Methylation as Diagnostic Biomarkers for PDAC}

Melnikov et al. (2009) was the first to publish a study on plasma DNA methylation changes as blood-based diagnostic biomarkers of PDAC. Using microarray analysis, the promoter region of five genes were detected as hypomethylated in cell-free DNA of PDAC patients $(n=30)$, reaching a $76 \%$ sensitivity and $59 \%$ specificity [26].

Liggett et al. (2010) used the same microarray analysis to identify seventeen gene promoter regions aberrantly methylated in plasma cell-free DNA when comparing patients with PDAC $(n=30)$, chronic pancreatitis $(n=30)$ and healthy individuals $(n=30)$. The gene panel reached a $90.8 \%$ sensitivity and a $91.2 \%$ specificity for PDAC when compared to chronic pancreatitis. In addition, a $78 \%$ sensitivity and a $81.7 \%$ specificity was demonstrated when differentiating patients with chronic pancreatitis and healthy individuals [27]. However, no further validation of the results has been published.

Park et al. examined in 2012 by methylation specific PCR promoter hypermethylation of a six gene panel (NPTX2, UCHL1, SARP2, ppENK, $p 16$ and RASSF1A) in plasma cellfree DNA of PDAC patients $(n=16)$, patients with chronic pancreatitis $(n=13)$, and healthy individuals $(n=29)$. Hypermethylation of all six genes were found both in plasma from patients with PDAC and patients with chronic pancreatitis, however the frequency was higher in cancer patients, although not statistically significant [28]. Afterwards, a study including 104 PDAC patients, 60 chronic pancreatitis patients, and five patients with benign gallstone disease focused on the methylation status of NPTX2 [29]. NPTX2 hypermethylation was found in pretreatment plasma from $84 \%$ of PDAC patients, 33\% of patients with chronic pancreatitis and none of the patients with benign gallstone disease $(p$-value $=0.016)$.

The methylation status of a panel of five tumor suppressor genes ( $p 16, p 14, R A S S F 1 A$, $A P C$ and DCC) was evaluated by Kawasaki et al. in 2013 [30]. PDAC patients $(n=47)$ were compared to patients with other types of cancer $(n=197)$. Pretreatment plasma was analyzed by methylation specific PCR. Hypermethylation of $p 16$ and RASSF1A was detected in $17 \%$ and $34 \%$ of patients with PDAC, respectively. Similar methylation frequency of $p 16$ and RASSF1A was seen for patients with several other types of cancer. Except for hepatocellular carcinoma where $73.3 \%$ of patients had hypermethylated $R A S S F 1 A$. Hypermethylation of APC, DCC and $p 14$ were also detected in PDAC patients, however less frequent [30].

In 2013 Joo Mi Yi et al. analyzed cell-free DNA promoter hypermethylation of BNC1 and ADAMTS1 in pretreatment serum from patients with PDAC $(n=42)$ and healthy volunteers $(n=26)$ [31]. The sensitivity was $79 \%$ and $48 \%$ for $B N C 1$ and ADAMTS1, respectively. Specificity was $89 \%$ for $B N C 1$ and $92 \%$ for ADAMTS1. In addition, $B N C 1$ and ADAMTS1 showed a promising sensitivity of $90 \%$ for stage I PDAC [31]. The results were validated in 39 patients with PDAC and 95 age-matched controls, and the combination of ADAMTS1 and BNC1 showed a convincing AUC of 0.95 (0.91-0.98) [32]. The panel was also analyzed in patients with chronic pancreatitis $(n=8)$. Unfortunately, seven of the eight patients with chronic pancreatitis were hypermethylated in either of the two genes, indicating the test fail to differentiate PDAC and chronic pancreatitis [32].

A recent study by Nidhi Singh et al. [33] examined methylation status of four genes (SPARC, UCHL1, PENK and NPTX2). Cell-free DNA in plasma of patients with PDAC $(n=61)$, patients with chronic pancreatitis $(n=22)$ and healthy controls $(n=21)$ were analyzed. To differentiate PDAC and chronic pancreatitis SPARC reached an AUC of 0.76 (0.65-0.87) and a similar performance was seen for early stage PDAC., whereas the other genes did not reach statistical significance between PDAC and chronic pancreatitis. In general, the methylation level of all four genes was significantly higher in PDAC patients compared with the healthy controls [33]. 
In 2015 primarily based on a literature review [34], which addressed genes aberrantly methylated in PDAC, a panel of 28 promoter regions was designed by our group and examined in both a diagnostic and prognostic biomarker study [35]. The aim was to evaluate the overall performance of genes previously examined separately as markers for PDAC. Cell-free DNA promoter hypermethylation in plasma was analyzed in a large cohort of PDAC patients $(n=95)$. A clinically relevant control groups of patients with chronic pancreatitis $(n=97)$, patient screened for but not having upper gastrointestinal cancer $(n=27)$ and patients with acute pancreatitis $(n=59)$ were included [35]. Based on a subgroup of eight genes from the panel a diagnostic prediction model (age $>65$ years, BMP3, RASSF1A, BNC1, MESTV2, TFPI2, APC, SFRP1 and SFRP2) for PDAC was developed reaching an AUC of 0.86 (95\% CI 0.81-0.91). Very importantly, the prediction model was independent of cancer stage. Subsequently, an external validation study of the diagnostic gene panel has been initiated, and in addition the additive effect of CA-19-9 was analyzed. So far, the results are promising, especially as the test is developed using patients with benign pancreatic disease as the control group, which enables differentiation of cancer specific hypermethylation and hypermethylation in response to an inflammatory pancreatic reaction, as observed in chronic or acute pancreatitis. This aspect is important because chronic pancreatitis is a significant risk factor for PDAC and the differentiation of patients with PDAC from patients with chronic pancreatitis is a known clinical challenge.

Recently other studies combining methylation analyses with other diagnostic modalities has been published. Fujimoto et al. analyzed methylation status of RUNX3 in plasma cell-free DNA in combination with CA-19-9 in patients with PDAC $(n=55)$, chronic pancreatitis $(n=12)$ and healthy volunteers $(n=80)$. RUNX3 methylation had a sensitivity of $50.9 \%$ for PDAC, with a $93.5 \%$ specificity using the total control group. By combining RUNX3 methylation and CA-19-9 the sensitivity increased substantial (85.5\%) [36]. Furthermore, Keiko Shinjo and coworkers [37] examined methylation status of five genes (ADAMTS1, HOXA1, PCDH10, SEMA5A and SPSB4 in serum from patients with PDAC $(n=47)$ and healthy controls $(n=14)$. The mean methylation level of the five genes in cell-free DNA was not significant different between cancer patients and controls. However, twenty-three PDAC patients had at least one of the genes methylated leading to a $49 \%$ sensitivity and an $86 \%$ specificity. Additionally, KRAS mutation in cell-free DNA was detected in twenty-three PDAC patients. When combining KRAS mutation and methylation status the diagnostic performance improved (68\% sensitivity and 86\% specificity) [37]. Both studies lack validation, which is needed to confirm the results.

Using various methods, which is outside the scope for this present review, the methylation status of a broad spectrum of genes has been analyzed in cell-free DNA in order to find genes with potential to work as diagnostic biomarkers for PDAC. Table 1 summarizes the above-mentioned diagnostic studies. Hypermethylation of several genes has been detected in plasma and serum from patients with PDAC. At low frequency hypermethylation of the same genes are also present in plasma and serum from patients with chronic pancreatitis and healthy controls [27,28,32,35]. In conclusion, cell-free DNA hypermethylation has the potential to work as diagnostic biomarkers for PDAC. However, none of the genes jet examined has the potential to function as an individual diagnostic marker and the performance of the previously described gene panels do not allow any of them to be used as a stand-alone test for PDAC diagnosis. Nevertheless, so far, the results from the validation study of the diagnostic gene panel developed by our group, which is based on hypermethylation of eight genes in combination with CA-19-9 shows a promising performance. This together with the other studies illustrating improved performance in combination with KRAS mutation [37] or CA-19-9 [36], indicate a panel of hypermethylated genes in combination with other diagnostic modalities might be needed to bolster the diagnostic power, which seems reasonable keeping in mind the molecular heterogenicity of PDAC. 
Table 1. Studies on cell-free DNA methylation in plasma/serum as diagnostic biomarkers for pancreatic adenocarcinoma.

\begin{tabular}{|c|c|c|c|c|c|c|c|c|}
\hline Reference & Genes & Method & Cases & Controls & Results & Strenghts & Limitations & Maturity Level * \\
\hline $\begin{array}{l}\text { Nidhi Singh } \\
\text { et al., } 2020 \text { [33] }\end{array}$ & $\begin{array}{l}\text { SPARC } \\
\text { UCHL1 } \\
\text { PENK } \\
\text { NPTX2 }\end{array}$ & MSP & PDAC 61 & $\begin{array}{l}\text { CP } 22 \\
\text { HC } 21\end{array}$ & $\begin{array}{l}\text { SPARC: AUC of } 0.76(0.65-0.87) \\
\text { The other genes did not reach } \\
\text { statistical significance. }\end{array}$ & $\begin{array}{l}\text { - Consecutive inclusion of } \\
\text { PDAC patients. } \\
\text { - Large group of well-defined cases. } \\
\text { - Inclusion of controls with benign } \\
\text { pancreatic disease. }\end{array}$ & $\begin{array}{l}\text { - Lack information on whether cases } \\
\text { and controls were matched according to } \\
\text { age, sex etc. } \\
\text { - No information on treatment before } \\
\text { blood sampling. }\end{array}$ & $\begin{array}{l}\text { Phase } 1 / \text { Phase } 2 \text {. } \\
\text { No further validation. }\end{array}$ \\
\hline $\begin{array}{l}\text { Fujimoto et al., } \\
2020[36]\end{array}$ & RUNX3 & $\begin{array}{l}\text { CORD } \\
\text { assay }\end{array}$ & PDAC 55 & $\begin{array}{l}\text { CP } 12 \\
\text { HC } 80\end{array}$ & $\begin{array}{c}\text { RUNX3: } \\
\text { Sens; } 50.9 \% \text {, Spec; } 93.5 \% \text { (the total } \\
\text { control group) } \\
\text { Combining RUNX3 and CA-19-9: } \\
\text { Sens; } 85.5 \% \text {, Spec; } 93,5 \%\end{array}$ & $\begin{array}{l}\text { - Large group of cases and controls. } \\
\text { - Inclusion of controls with benign } \\
\text { pancreatic disease. }\end{array}$ & $\begin{array}{l}\text { - Not matched according to age and sex. } \\
\text { - No information on treatment before } \\
\text { blood sampling. }\end{array}$ & $\begin{array}{l}\text { Phase } 1 / \text { Phase } 2 \text {. } \\
\text { No validation studies. }\end{array}$ \\
\hline $\begin{array}{l}\text { Shinjo et al., } \\
2020 \text { [37] }\end{array}$ & $\begin{array}{l}\text { ADAMTS1 } \\
\text { HOXA1 } \\
\text { PCDH10 } \\
\text { SEMA5A } \\
\text { SPSB4 } \\
\text { SFRP2 }\end{array}$ & qMSP & PDAC 47 & HC 14 & $\begin{array}{l}\text { The panel of five genes (with at least one gene } \\
\text { methylated): Sens; } 49 \% \text {, Spec; } 86 \% \\
\text { Combining the gene panel and KRAS mutation } \\
\text { in cell-free DNA: Sens; } 68 \% \text {, Spec; } 86 \%\end{array}$ & $\begin{array}{l}\text { - Well described and comprehensive } \\
\text { analysis of tissue samples. } \\
\text { - Pretreatment blood samples. } \\
\text { - Cases and controls matched according } \\
\text { to age and sex. }\end{array}$ & $\begin{array}{l}\text { - Lacking a control group of patients } \\
\text { with benign pancreatic disease. }\end{array}$ & $\begin{array}{l}\text { Phase } 1 / \text { Phase } 2 \text {. } \\
\text { No validation studies }\end{array}$ \\
\hline $\begin{array}{l}\text { Henriksen et al., } \\
\quad 2017 \text { [25] }\end{array}$ & $\begin{array}{c}\text { SFRP1 } \\
\text { APC } \\
\text { TFPI2 } \\
\text { MESTV2 } \\
\text { BNC1 } \\
\text { RASSF1A } \\
\text { BMP3 }\end{array}$ & MSP & PDAC 95 & $\begin{array}{l}\text { CP } 97 \\
\text { SN } 27\end{array}$ & $\begin{array}{l}\text { Prediction model combining hypermethylation } \\
\text { status of the eight genes and age < } 65 \text { years: } \\
\text { PDAC vs. CP and SN: AUC } 0.86(0.81-0.91)\end{array}$ & $\begin{array}{l}\text { - Consecutive inclusion of } \\
\text { PDAC patients. } \\
\text { - Large group of cases and controls with } \\
\text { benign pancreatic disease. } \\
\text { - Pretreatment plasma }\end{array}$ & $\begin{array}{l}\text { - Cases and controls not age-matched. } \\
\text { - The gene-panel is not analyzed in } \\
\text { tumor tissue. }\end{array}$ & $\begin{array}{l}\text { Phase } 1 / \text { Phase } 2 \text {. } \\
\text { An external validation } \\
\text { study is initiated. }\end{array}$ \\
\hline $\begin{array}{l}\text { Eissa et al., } 2019 \\
{[\text { [32] }}\end{array}$ & $\begin{array}{c}B N C 1 \\
\text { ADAMTS1 }\end{array}$ & $\begin{array}{l}\text { MOB and } \\
\text { qMSP }\end{array}$ & PDAC 39 & $\begin{array}{l}\mathrm{HC} 95 \\
\mathrm{CP} 8\end{array}$ & $\begin{array}{c}\text { Combining BNC1 and ADAMTS1: } \\
\text { PDAC vs HC: AUC } 0.95 \text { (0.91-0.98) } \\
\text { CP: } 7 / 8 \text { were had either BNC1 or ADAMTS1 } \\
\text { methylated. }\end{array}$ & $\begin{array}{l}\text { - Population-based matched and } \\
\text { age-matched controls. } \\
\text { - Pretreatment serum. }\end{array}$ & $\begin{array}{l}\text { - Small control group of CP patients } \\
\text { - Racial difference between cases } \\
\text { and controls. }\end{array}$ & $\begin{array}{l}\text { Phase 1/Phase } 2 . \\
\text { Validation study of Joo } \\
\text { Mi Yi et al., 2013 [31]. }\end{array}$ \\
\hline $\begin{array}{l}\text { Joo Mi Yi et al., } \\
2013 \text { [31] }\end{array}$ & $\begin{array}{c}\text { BNC1 } \\
\text { ADAMTS1 }\end{array}$ & МОВ & PDAC 42 & HC 26 & $\begin{array}{c}\text { BNC1: PDAC 79\% (33/42), HC } 11,5 \%(3 / 26) \\
\text { ADAMTS1: PDAC } 48 \%(20 / 42), \text { HC } 7.7 \% \\
(2 / 26) \\
\text { Combining BNC1 and ADAMTS1 did not } \\
\text { improve sensitivity and specificity. }\end{array}$ & $\begin{array}{l}\text { - Well described and comprehensive } \\
\text { analysis of cell-lines and tissue samples. } \\
\text { - Pretreatment serum. }\end{array}$ & $\begin{array}{l}\text { - Lack information on whether cases } \\
\text { and controls were matched according to } \\
\text { age, sex etc. } \\
\text { - Lacking a control group of patients } \\
\text { with benign pancreatic disease }\end{array}$ & $\begin{array}{l}\text { Phase } 1 \text { and phase } 2 . \\
\text { One validation study is } \\
\text { performed (Eissa et al., } \\
2019 \text { [32]). }\end{array}$ \\
\hline $\begin{array}{l}\text { Kawasaki et al., } \\
2013 \text { [30] }\end{array}$ & $\begin{array}{c}\text { APC } \\
\text { DCC } \\
P 16 \\
P 14 \\
\text { RASSF1A }\end{array}$ & MSP & PDAC 47 & $\begin{array}{l}\text { Patients } \\
\text { with } \\
\text { other } \\
\text { types of } \\
\text { cancer } \\
197\end{array}$ & $\begin{array}{c}\text { APC: } 23.4 \%(11 / 47) \\
\text { DCC: } 6.4 \%(3 / 47) \\
\text { P16: } 17 \%(8 / 47) \\
\text { P14: } 14.9 \%(7 / 47) \\
\text { RASSF1A: } 34 \%(16 / 47)\end{array}$ & $\begin{array}{l}\text { - Pretreatment plasma. } \\
\text { - Large cohort of cases. }\end{array}$ & $\begin{array}{l}\text { - Lack of HC or controls of patients with } \\
\text { benign pancreatic disease. }\end{array}$ & $\begin{array}{l}\text { Phase } 1 / \text { Phase } 2 \text {. } \\
\text { No validation studies. }\end{array}$ \\
\hline $\begin{array}{l}\text { Park, Ryu et al., } \\
2012[29]\end{array}$ & NPTX2 & qMSP & $\begin{array}{l}\text { PDAC } \\
104\end{array}$ & $\begin{array}{l}\text { CP } 60 \\
\text { GD } 5\end{array}$ & $\begin{array}{c}\text { Frequency of hypermethylation: } \\
\text { PDAC: } 84 \%(87 / 104) \\
\text { CP: } 33 \%(20 / 60) \\
\text { GD: } 0 \%(0 / 5) \\
\text { Statistically significant difference }(P=0.016)\end{array}$ & $\begin{array}{l}\text { - Pretreatment plasma. } \\
\text { - Large cohort of cases and controls. } \\
\text { - Include controls with benign } \\
\text { pancreatic disease. }\end{array}$ & $\begin{array}{l}\text { - Not age matched cases and controls } \\
\text { - No description of inclusion period. }\end{array}$ & $\begin{array}{l}\text { Phase } 1 / \text { Phase } 2 . \\
\text { A validation study of } \\
\text { NPTX2 (Park, Baek } \\
\text { et al., 2012 [28]). } \\
\text { No further validation. }\end{array}$ \\
\hline
\end{tabular}


Table 1. Cont.

\begin{tabular}{|c|c|c|c|c|c|c|c|c|}
\hline Reference & Genes & Method & Cases & Controls & Results & Strenghts & Limitations & Maturity Level * \\
\hline $\begin{array}{l}\text { Park, Baek et al., } \\
\quad 2012[28]\end{array}$ & $\begin{array}{l}\text { NPTX2 } \\
\text { UCHL1 } \\
\text { SARP2 } \\
\text { PpENK } \\
\text { P16 } \\
\text { RASSF1A }\end{array}$ & MSP & PDAC 16 & $\begin{array}{l}\text { CP } 13 \\
\text { HC } 29\end{array}$ & $\begin{array}{c}\text { Frequency of hypermethylation: } \\
\text { NPTX2: PDAC 6/16, CP 2/13, HC 0/29 } \\
\text { UCHL1: PDAC 4/16, CP 2/13, HC 0/29 } \\
\text { SARP2: PDAC 5/16, CP 3/13, HC 0/29 } \\
\text { ppENK: PDAC 5/16, CP 2/13, HC 0/29 } \\
\text { P16: PDAC 4/16, CP 2/13, HC } 1 / 29 \\
\text { RASSF1A: PDAC 1/16, CP 1/13, HC 0/29 } \\
\text { No statistically significant difference. } \\
\text { - 8 gene promoters could differentiate CP }\end{array}$ & $\begin{array}{l}\text { - Include controls with benign } \\
\text { pancreatic disease. }\end{array}$ & $\begin{array}{l}\text { - Small cohort of cases and controls. } \\
\text { - No information on treatment before } \\
\text { blood sampling. } \\
\text { - Not age-matched cases and controls. }\end{array}$ & $\begin{array}{c}\text { Phase 1/Phase } 2 . \\
\text { NPTX2 was } \\
\text { subsequently validated } \\
\text { (Park, Ryu et al., } 2012 \\
\text { [29]). } \\
\text { No further validation. }\end{array}$ \\
\hline $\begin{array}{l}\text { Liggett et al., } \\
2010[27]\end{array}$ & & MethDet56 & PDAC 30 & $\begin{array}{l}\text { CP } 30 \\
\text { HC } 30\end{array}$ & $\begin{array}{c}\text { - } 8 \text { gene promoters could difterentiate CP } \\
\text { and HC: } \\
\text { Sens; } 78.0 \% \text {, Spec; } 81.7 \% \\
\text { - } 14 \text { gene promoters could differentiate PDAC } \\
\text { and CP: } \\
\text { Sens; } 90.8 \% \text {, Spec; } 91.2\end{array}$ & $\begin{array}{l}\text { - Cases and controls matched on sex, } \\
\text { age and race. } \\
\text { - Detailed description of CP patients. } \\
\text { - Pretreatment plasma. }\end{array}$ & $\begin{array}{l}\text { - No information on whether the } \\
\text { aberrantly methylated genes were hypo- } \\
\quad \text { or hypermethylated. } \\
\text { - No description of inclusion period }{ }^{* *} \text {. }\end{array}$ & $\begin{array}{c}\text { Phase } 1 / \text { Phase } 2 \text {. } \\
\text { No validation studies. }\end{array}$ \\
\hline $\begin{array}{l}\text { Melnikov et al., } \\
2009[26]\end{array}$ & & MethDet56 & PDAC 30 & $\begin{array}{l}\text { CP } 30 \\
\mathrm{HC} 30\end{array}$ & $\begin{array}{l}\text { Based on five hypomethylated } \\
\text { promoter regions: } \\
\text { Sens; } 76 \% \text {, Spec; } 59 \%\end{array}$ & $\begin{array}{l}\text { - Cases and controls matched on sex } \\
\text { and age. }\end{array}$ & $\begin{array}{l}\text { - No description of inclusion period }{ }^{* *} \text {. } \\
\text { - No information on treatment before } \\
\text { blood sampling. }\end{array}$ & $\begin{array}{l}\text { Phase } 1 / \text { Phase } 2 \text {. } \\
\text { No validation studies. }\end{array}$ \\
\hline
\end{tabular}

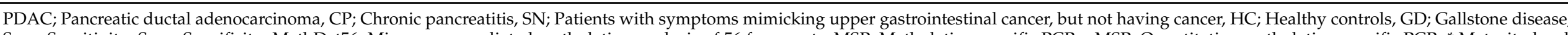

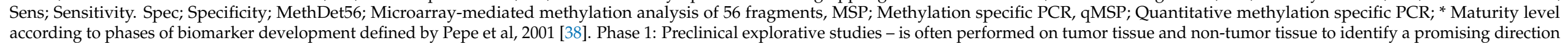

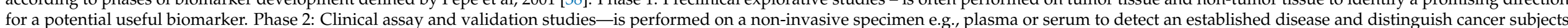

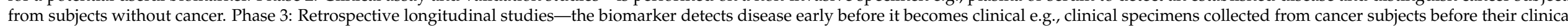

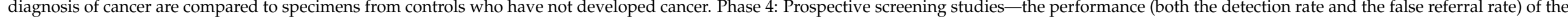

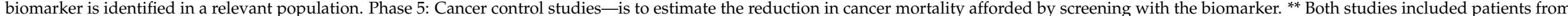
the same center, as none of the studies describe the inclusion period, it is impossible to exclude patient overlap. 
The studies of DNA methylation have brought us closer to a diagnostic biomarker for PDAC, but we are not quite there yet. Many studies are of small sample size and still lack validation. According to the five-phase structure of biomarker development described by Pepe et al. [38] studies on DNA methylation as diagnostic biomarkers for PDAC only reach phase 2 (see Table 1). Currently, no diagnostic biomarker for PDAC based on cellfree DNA methylation has reach phase 3, which involves a retrospective longitudinal study of clinical specimens collected from cancer patients before their clinical diagnosis. In addition, no phase 4 studies (prospective studies) or phase 5 studies, which estimate the reduction of cancer mortality afforded by the biomarker, do exist. In general, further research is needed. Well-designed validation studies, including both patients with benign and malignant pancreatic disease (etc. patients with late-onset diabetes and individuals with a familiar disposition to PDAC) testing broad gene-panels in combination with other diagnostic modalities will hopefully get closer to a clinical useful diagnostic marker.

\section{Cell-Free DNA Methylation as Prognostic Biomarkers for PDAC}

As mentioned earlier a progressive increase in aberrant DNA methylation, both hyperand hypomethylation, has been demonstrated with increasing dysplasia [23,24], indicating there to be a prognostic potential in DNA methylation changes.

In general, only very few studies on the prognostic value of hypermethylated cell-free DNA in PDAC do exist. In 2017 our group investigated cell-free DNA in PDAC regard to stage classification and survival [25,39].

\subsection{Number of Hypermethylated Genes According to Cancer Stage and Survival}

Similar to other studies, a study by our group demonstrated that hypermethylated cellfree DNA is detectable in all stages of PDAC [25,35,39]. Furthermore, the study discovered that patients with distant metastases had an even higher number of hypermethylated genes in cell-free DNA compared with patients with localized disease [25]. Distant metastasis has previously been reported to result in a larger amount of cell-free DNA [10]. However, the level of cell-free DNA was not associated with cancer stage in our study [25]. The study of Park et al. [28] was not able to show similar association between metastatic PDAC and a higher number of hypermethylated genes in cell-free DNA, which could be due to a lack of power or differences in genes analyzed. However, our results on cell-free DNA are consistent with a study on PDAC tumor tissue [23]. These observations suggest that hypermethylated promoter regions accumulate during the course of PDAC development and progression.

Another study by our group demonstrated that the number of hypermethylated genes in cell-free DNA was associated with survival. Patients with more than ten hypermethylated genes were more likely to die during the first year after diagnosis than patients with fewer hypermethylated genes [39]. Similar association between number of hypermethylated genes and poor survival has been reported for head and neck cancer [40].

\subsection{Methylated Genes Associated with Distant Metastasis}

Cell-free DNA hypermethylation of seven individual genes ALX4, BNC1, HIC1, SEPT9v2, SST, TFPI2, and TAC1 has been associated with distant metastasis in a study by our group [25]. Likewise, HIC1 hypermethylation in tumor tissue has previously been detected in PDAC stage III-IV [41]. In addition, Park et al. described cell-free DNA hypermethylation of NPTX2 to increase significantly with aggravating tumor stage [28]. Nidhi Singh and coworkers [33] also found cell-free DNA hypermethylation of NPTX2 and SPARC to be more pronounced in stage IV PDAC. Similar prognostic value of NPTX2 was not found in our study.

\subsection{Methylated Genes According to Cancer Stage}

To enable differentiation of PDAC patients according to cancer stage two prediction models were developed by our group [25]. A panel based on the hypermethylation status of 
eight genes (SEPT9v2, SST, ALX4, CDKN2B, HIC1, MLH1, NEUROG1, and BNC1) enabled with high performance (AUC of 0.87 ) the distinction of stage IV PDAC patients from PDAC patients with stage I-III. Another panel (MLH1, SEPT9v2, BNC1, ALX4, CDKN2B, NEUROG1, WNT5A, and TFPI2) enabled the differentiation of potentially resectable disease (stage I and II) from non-resectable disease (stage III and IV) (AUC of 0.82) [25].

\subsection{Methylated Genes According to Survival}

Furthermore, the association between cell-free DNA hypermethylation and survival of PDAC patients was investigated by our group [39]. Overall, promoter hypermethylation had a negative impact on survival. However, hypermethylation of a few specific genes had a positive effect on survival. Hypermethylation of SFRP1, BMP3, and TFPI2 was significantly associated with impaired survival in stage IV disease [39]. In concordance with our findings, hypermethylation of SFRP1 in tumor tissue has been identified as an independent risk factor for poor overall survival in breast cancer [42] and renal cancer [43]. In addition, hypermethylation of TFPI2 in hepatocellular carcinoma tumor tissue is associated with advanced cancer stage and shorter survival [44], similar to our results for cell-free DNA in PDAC.

Based on hypermethylated cell-free DNA prediction models for survival of patients with PDAC were developed [39], which enabled the stratification of patients in risk groups according to survival. The results indicate a biological variation within pancreatic adenocarcinoma that influences patient outcome. These findings are consistent with a study of PDAC tissue [45] describing a methylation signature associated with short survival time and another methylation signature associated with long survival time. Likewise, Minqi Gu et al. [46] identified a four-gene methylation signature (CCNT1, ITGB3, SDS and $H M O X 2$ ) in tumor tissue to predict the prognosis of PDAC patients. Based on the methylation signature patients were divided into a high-risk and a low-risk group [46]. These results indicate that DNA hypermethylation has the potential to provide prognostic information in addition to the TNM classification, which clearly would benefit patients and clinicians' therapeutic decisions and facilitate the correct choice of treatment.

No doubt, cell-free DNA methylation has prognostic potential as blood-based biomarkers. Nevertheless, the studies in the area are few and validation of the results are lacking. An external validation of the prognostic biomarker studies by our group has just been initiated. Unfortunately, it is still too early to say anything about the outcome. Further research is needed, as well as well-designed prospective studies tracking the methylation profile in cell-free DNA of PDAC patients according to prognosis, treatment and recurrence are.

\section{Conclusions}

The current literature discussed above, clearly indicates that cell-free DNA methylation has the potential to be the fundament of useful blood-based diagnostic and prognostic biomarkers for PDAC, however further research is still needed before clinical application (Table 2).

Table 2. Summary of Recommended Future Directions for the Field.

- Cases and controls matched according to age, sex and race.

- The use of pretreatment blood samples.

- Studies combining methylated gene-panels and other diagnostic modalities.

- Large validation studies including cases with early stage cancer and controls with benign pancreatic disease.

- Validation on cases with pancreatic cancer precursor lesions.

- Validation on cases with increased risk of pancreatic cancer e.g., subjects with a risk of familial pancreatic cancer and subjects with diabetes.

- Retrospective longitudinal studies.

- Prospective screening studies of subjects with increased risk of pancreatic cancer. 
Author Contributions: S.D.H. drafted the first version of the paper. O.T.-U. and S.D.H. both revised the draft and approved the final version of the paper. All authors have read and agreed to the published version of the manuscript.

Funding: This research received no external funding.

Institutional Review Board Statement: Not applicable.

Informed Consent Statement: Not applicable.

Acknowledgments: We would like to express our gratitude to the entire staff at the Department of Gastrointestinal Surgery, Aalborg University, Denmark.

Conflicts of Interest: Aalborg University Hospital is currently applying for patents relating the diagnostic gene panel [35]. The authors declare no personal conflict of interest.

\begin{tabular}{|c|c|}
\hline Pancreatic adenocarcinoma & $(\mathrm{PDAC})$ \\
\hline Carbohydrate antigen-19-9 & $(\mathrm{CA}-19-9)$ \\
\hline \multicolumn{2}{|l|}{ List of Genes: } \\
\hline ADAMTS1 & A disintegrin and metalloproteinase with thrombospondin motifs 1 \\
\hline$A P C$ & Adenomatous polyposis coli \\
\hline$A L X 4$ & Homebox Protein Aristaless-Like 4 \\
\hline$B N C 1$ & Basonuclin 1 \\
\hline BMP3 & Bone Morphogenetic Protein 3 \\
\hline CCNT1 & Cyclin T1 \\
\hline CDKN2A & Cycklin-Dependent Kinase Inhibitor 2A (p16) \\
\hline CDKN2B & Cycklin-Dependent Kinase Inhibitor 2B (p15) \\
\hline$D C C$ & Deleted in Colorectal Carcinoma \\
\hline HMOX2 & Heme Oxygenase 2 \\
\hline HOXA1 & Homeobox protein Hox A1 \\
\hline HIC1 & Hypermethylated in Cancer 1 \\
\hline ITGB3 & Integrin beta- 3 \\
\hline MESTv2 & Mesoderm Specific Transcript 2 \\
\hline MLH1 & MutL Homolog 1 \\
\hline NEUROG1 & Neurogenin 1 \\
\hline NPTX2 & Neuronal pentraxin 2 \\
\hline ppENK & Preproenkephalin \\
\hline PCDH10 & Protocadherin 10 \\
\hline RASSF1A & Rras associated domain family member 1 \\
\hline RUNX3 & Runt-related transcription factor 3 \\
\hline SARP1 & Secreted apoptose related protein 1 \\
\hline$S A R P 2$ & Secreted apoptose related protein 2 \\
\hline SPARC & Secreted Protein Acidic and Cysteine Rich (SPARC) \\
\hline SEMA5A & Semaphorin $5 \mathrm{~A}$ \\
\hline SEPT9v2 & Septin 9 Transcript Variant 2 \\
\hline$S D S$ & Serine Dehydratase \\
\hline SST & Somatostatin \\
\hline SPSB4 & SplA/Ryanodine Receptor Domain and SOCS Box Containing 4 \\
\hline TAC1 & Tachykinin Precusor 1 \\
\hline TFPI2 & Tissue factor pathway inhibitor 2 \\
\hline UCHL1 & Ubiquitin carboxy-terminal hydrolase L1 \\
\hline WNT5A & Wingless-Type MMTV Integration Site Family, Member 5A \\
\hline
\end{tabular}

\section{References}

1. Siegel, R.L.; Miller, K.D.M.; Jemal, A. Cancer statistics, 2018. CA Cancer J. Clin. 2018, 68, 7-30. [CrossRef] [PubMed]

2. Hartwig, W.; Strobel, O.; Hinz, U.; Fritz, S.; Hackert, T.; Roth, C.; Büchler, M.W.; Werner, J. CA19-9 in Potentially Resectable Pancreatic Cancer: Perspective to Adjust Surgical and Perioperative Therapy. Ann. Surg. Oncol. 2012, 20, 2188-2196. [CrossRef] [PubMed] 
3. Poruk, K.E.; Gay, D.Z.; Brown, K.; Mulvihill, J.D.; Boucher, K.M.; Scaife, C.L.; Firpo, M.A.; Mulvihill, S.J. The Clinical Utility of CA 19-9 in Pancreatic Adenocarcinoma: Diagnostic and Prognostic Updates. Curr. Mol. Med. 2013, 13, 340-351. [CrossRef]

4. Haab, B.B.; Huang, Y.; Balasenthil, S.; Partyka, K.; Tang, H.; Anderson, M.; Allen, P.; Sasson, A.; Zeh, H.; Kaul, K.; et al. Definitive Characterization of CA 19-9 in Resectable Pancreatic Cancer Using a Reference Set of Serum and Plasma Specimens. PLoS ONE 2015, 10, e0139049. [CrossRef] [PubMed]

5. Zhang, Y.; Yang, J.; Li, H.; Wu, Y.; Zhang, H.; Chen, W. Tumor markers CA19-9, CA242 and CEA in the diagnosis of pancreatic cancer: A meta-analysis. Int. J. Clin. Exp. Med. 2015, 8, 11683-11691. [PubMed]

6. $\quad$ Kim, J.-E.; Lee, K.T.; Lee, J.K.; Paik, S.W.; Rhee, J.C.; Choi, K.W. Clinical usefulness of carbohydrate antigen 19-9 as a screening test for pancreatic cancer in an asymptomatic population. J. Gastroenterol. Hepatol. 2004, 19, 182-186. [CrossRef] [PubMed]

7. Goggins, M.; Overbeek, K.A.; Brand, R.; Syngal, S.; Del Chiaro, M.; Bartsch, D.K.; Bassi, C.; Carrato, A.; Farrell, J.; Fishman, E.K.; et al. Management of patients with increased risk for familial pancreatic cancer: Updated recommendations from the International Cancer of the Pancreas Screening (CAPS) Consortium. Gut 2020, 69, 7-17. [CrossRef]

8. Ryan, D.P.; Hong, T.S.; Bardeesy, N. Pancreatic Adenocarcinoma. N. Engl. J. Med. 2014, 371, 1039-1049. [CrossRef]

9. Mattox, A.K.; Bettegowda, C.; Zhou, S.; Papadopoulos, N.; Kinzler, K.W.; Vogelstein, B. Applications of liquid biopsies for cancer. Sci. Transl. Med. 2019, 11, eaay1984. [CrossRef]

10. Bettagowda, C.; Sausen, M.; Leary, R.J.; Kinde, I.; Wang, Y.; Agrawal, N.; Bartlett, B.R.; Wang, H.; Luber, B.; Alani, R.M.; et al. Dectection of circulating tumor DNA in early- and late-stage human malignancies. Sci. Transl. Med. 2014, 6, 69-122. [CrossRef]

11. Siravegna, G.; Mussolin, B.; Venesio, T.; Marsoni, S.; Seoane, J.; Dive, C.; Papadopoulos, N.; Kopetz, S.; Corcoran, R.; Siu, L.; et al. How liquid biopsies can change clinical practice in oncology. Ann. Oncol. 2019, 30, 1580-1590. [CrossRef]

12. Parikh, A.R.; Leshchiner, I.; Corcoran, R.B. Liquid versus tissue biopsy for detecting acquired resistance and tumor heterogeneity in gastrointestinal cancers. Nat. Med. 2019, 25, 1415-1421. [CrossRef]

13. Siravegna, G.; Marsoni, S.; Siena, S.; Bardelli, A. Integrating liquid biopsies into the management of cancer. Nat. Rev. Clin. Oncol. 2017, 14, 531-548. [CrossRef] [PubMed]

14. Schwarzenbach, H.; Hoon, D.S.B.; Pantel, K. Cell-free nucleic acids as biomarkers in cancer patients. Nat. Rev. Cancer 2011, 11, 426-437. [CrossRef]

15. Leon, S.A.; Shapiro, B.; Sklaroff, D.M.; Yaros, M.J. Free DNA in the serum of cancer patients and the effect of therapy. Cancer Res. 1977, 37, 646-650. [PubMed]

16. Shapiro, B.; Chakrabarty, M.; Cohn, E.M.; Leon, S.A. Determination of circulating DNA levels in patients with benign or malignant gastrointestinal disease. Cancer 1983, 51, 2116-2120. [CrossRef]

17. Thierry, A.R.; El Messaoudi, S.; Gahan, P.B.; Anker, P.; Stroun, M. Origins, structures, and functions of circulating DNA in oncology. Cancer Metastasis Rev. 2016, 35, 347-376. [CrossRef]

18. Van Der Pol, Y.; Mouliere, F. Toward the Early Detection of Cancer by Decoding the Epigenetic and Environmental Fingerprints of Cell-Free DNA. Cancer Cell 2019, 36, 350-368. [CrossRef] [PubMed]

19. Mouliere, F.; Rosenfeld, N. Circulating tumor-derived DNA is shorter than somatic DNA in plasma. Proc. Natl. Acad. Sci. USA 2015, 112, 3178-3179. [CrossRef]

20. Delpu, Y.; Hanoun, N.; Lulka, H.; Sicard, F.; Selves, J.; Buscail, L.; Torrisani, J.; Cordelier, P. Genetic and Epigenetic Alterations in Pancreatic Carcinogenesis. Curr. Genom. 2011, 12, 15-24. [CrossRef]

21. Lomberk, G.A. Epigenetic Silencing of Tumor Suppressor Genes in Pancreatic Cancer. J. Gastrointest. Cancer 2011, 42, 93-99. [CrossRef]

22. Lomberk, G.; Dusetti, N.; Iovanna, J.; Urrutia, R. Emerging epigenomic landscapes of pancreatic cancer in the era of precision medicine. Nat. Commun. 2019, 10, 3875. [CrossRef] [PubMed]

23. Sato, N.; Fukushima, N.; Hruban, R.H.; Goggins, M. CpG island methylation profile of pancreatic intraepithelial neoplasia. Mod. Pathol. 2007, 21, 238-244. [CrossRef] [PubMed]

24. Sato, N.; Ueki, T.; Fukushima, N.; Iacobuzio-Donahue, C.A.; Hruban, R.H.; Goggins, M.; Yeo, C.J.; Cameron, J.L. Aberrant methylation of CpG islands in intraductal papillary mucinous neoplasms of the pancreas. Gastroenterology 2002, 123, 365-372. [CrossRef]

25. Henriksen, S.D.; Madsen, P.H.; Larsen, A.C.; Johansen, M.B.; Pedersen, I.S.; Krarup, H.; Thorlacius-Ussing, O. Promoter hypermethylation in plasma-derived cell-free DNA as a prognostic marker for pancreatic adenocarcinoma staging. Int. J. Cancer 2017, 141, 2489-2497. [CrossRef]

26. Melnikov, A.A.; Scholtens, D.; Talamonti, M.S.; Bentrem, D.J.; Levenson, V.V. Methylation profile of circulating plasma DNA in patients with pancreatic cancer. J. Surg. Oncol. 2009, 99, 119-122. [CrossRef]

27. Liggett, T.; Melnikov, A.; Yi, Q.-L.; Replogle, C.; Brand, R.; Kaul, K.; Talamonti, M.; Abrams, R.A.; Levenson, V. Differential methylation of cell-free circulating DNA among patients with pancreatic cancer versus chronic pancreatitis. Cancer 2010, 116, 1674-1680. [CrossRef] [PubMed]

28. Park, J.W.; Baek, I.H.; Kim, Y.T. Preliminary study analyzing the methylated genes in the plasma of patients with pancreatic cancer. Scand. J. Surg. 2012, 101, 38-44. [CrossRef]

29. Park, J.K.; Ryu, J.K.; Yoon, W.J.; Lee, S.H.; Lee, G.Y.; Jeong, K.-S.; Kim, Y.-T.; Yoon, Y.B. The Role of Quantitative NPTX2 Hypermethylation as a Novel Serum Diagnostic Marker in Pancreatic Cancer. Pancreas 2012, 41, 95-101. [CrossRef] [PubMed] 
30. Kawasaki, H.; Igawa, E.; Kohosozawa, R.; Kobayashi, M.; Nishiko, R.; Abe, H. Detection of aberrant methylation of tumor suppressor genes in plasma from cancer patients. Pers. Med. Univ. 2013, 2, 20-24. [CrossRef]

31. Yi, J.M.; Guzzetta, A.A.; Bailey, V.J.; Downing, S.R.; Van Neste, L.; Chiappinelli, K.B.; Keeley, B.P.; Stark, A.; Herrera, A.; Wolfgang, C.; et al. Novel Methylation Biomarker Panel for the Early Detection of Pancreatic Cancer. Clin. Cancer Res. 2013, 19, $6544-6555$. [CrossRef] [PubMed]

32. Eissa, M.A.L.; Lerner, L.; Abdelfatah, E.; Shankar, N.; Canner, J.K.; Hasan, N.M.; Yaghoobi, V.; Huang, B.; Kerner, Z.; Takaesu, F.; et al. Promoter methylation of ADAMTS1 and BNC1 as potential biomarkers for early detection of pancreatic cancer in blood. Clin. Epigenet. 2019, 11, 59. [CrossRef] [PubMed]

33. Singh, N.; Rashid, S.; Rashid, S.; Dash, N.R.; Gupta, S.; Saraya, A. Clinical significance of promoter methylation status of tumor suppressor genes in circulating DNA of pancreatic cancer patients. J. Cancer Res. Clin. Oncol. 2020, 146, 897-907. [CrossRef] [PubMed]

34. Henriksen, S.D.; Madsen, P.H.; Krarup, H.; Thorlacius-Ussing, O. DNA Hypermethylation as a Blood-Based Marker for Pancreatic Cancer. Pancreas 2015, 44, 1036-1045. [CrossRef]

35. Henriksen, S.D.; Madsen, P.H.; Larsen, A.C.; Johansen, M.B.; Drewes, A.M.; Pedersen, I.S.; Krarup, H.; Thorlacius-Ussing, O. Cell-free DNA promoter hypermethylation in plasma as a diagnostic marker for pancreatic adenocarcinoma. Clin. Epigenet. 2016, 8, 1-12. [CrossRef] [PubMed]

36. Fujimoto, Y.; Suehiro, Y.; Kaino, S.; Suenaga, S.; Tsuyama, T.; Matsui, H.; Higaki, S.; Fujii, I.; Suzuki, C.; Hoshida, T.; et al. Combination of CA19-9 and Blood Free-Circulating Methylated RUNX3 May Be Useful to Diagnose Stage I Pancreatic Cancer. Oncology 2021, 8505, 1-6. [CrossRef]

37. Shinjo, K.; Hara, K.; Nagae, G.; Umeda, T.; Katsushima, K.; Suzuki, M.; Murofushi, Y.; Umezu, Y.; Takeuchi, I.; Takahashi, S.; et al. A novel sensitive detection method for DNA methylation in circulating free DNA of pancreatic cancer. PLoS ONE 2020, 15, e0233782. [CrossRef]

38. Pepe, M.S.; Etzioni, R.; Feng, Z.; Potter, J.D.; Thompson, M.L.; Thornquist, M.D.; Winget, M.; Yasui, Y. Phases of Biomarker Development for Early Detection of Cancer. J. Natl. Cancer Inst. 2001, 93, 1054-1061. [CrossRef]

39. Henriksen, S.D.; Madsen, P.H.; Larsen, A.C.; Johansen, M.B.; Pedersen, I.S.; Krarup, H.; Thorlacius-Ussing, O. Cell-free DNA promoter hypermethylation in plasma as a predictive marker for survival of patients with pancreatic adenocarcinoma. Oncotarget 2017, 8, 93942-93956. [CrossRef]

40. Misawa, K.; Mochizuki, D.; Imai, A.; Endo, S.; Mima, M.; Misawa, Y.; Kanazawa, T.; Carey, T.E.; Mineta, H. Prognostic value of aberrant promoter hypermethylation of tumor-related genes in early-stage head and neck cancer. Oncotarget 2016, 7, 26087-26098. [CrossRef]

41. Zhao, G.; Qin, Q.; Zhang, J.; Liu, Y.; Deng, S.; Liu, L.; Wang, B.; Tian, K.; Wang, C. Hypermethylation of HIC1 Promoter and Aberrant Expression of HIC1/SIRT1 Might Contribute to the Carcinogenesis of Pancreatic Cancer. Ann. Surg. Oncol. 2012, 20, 301-311. [CrossRef]

42. Veeck, J.; Niederacher, D.; An, H.; Klopocki, E.; Wiesmann, F.; Betz, B.; Galm, O.; Camara, O.; Dürst, M.; Kristiansen, G.; et al. Aberrant methylation of the Wnt antagonist SFRP1 in breast cancer is associated with unfavourable prognosis. Oncogene 2006, 25, 3479-3488. [CrossRef]

43. Ricketts, C.J.; Hill, V.K.; Linehan, W.M. Tumor-Specific Hypermethylation of Epigenetic Biomarkers, Including SFRP1, Predicts for Poorer Survival in Patients from the TCGA Kidney Renal Clear Cell Carcinoma (KIRC) Project. PLoS ONE 2014, 9, e85621. [CrossRef] [PubMed]

44. Sun, F.-K.; Sun, Q.; Fan, Y.-C.; Gao, S.; Zhao, J.; Li, F.; Jia, Y.-B.; Liu, C.; Wang, L.-Y.; Li, X.-Y.; et al. Methylation of tissue factor pathway inhibitor 2 as a prognostic biomarker for hepatocellular carcinoma after hepatectomy. J. Gastroenterol. Hepatol. 2016, 31, 484-492. [CrossRef]

45. Thompson, M.J.; Rubbi, L.; Dawson, D.W.; Donahue, T.R.; Pellegrini, M. Pancreatic Cancer Patient Survival Correlates with DNA Methylation of Pancreas Development Genes. PLoS ONE 2015, 10, e128814. [CrossRef] [PubMed]

46. Gu, M.; Sun, J.; Zhang, S.; Chen, J.; Wang, G.; Ju, S.; Wang, X. A novel methylation signature predicts inferior outcome of patients with PDAC. Aging 2021, 13, 2851-2863. [CrossRef] [PubMed] 